\title{
How do root and soil characteristics affect the erosion-reducing potential of plant
}

\section{species?}

\author{
W. Vannoppen ${ }^{1}$, S. De Baets2, J. Keeble ${ }^{1}$, Y. Dong ${ }^{3}$, J. Poesen ${ }^{1}$
}

1 KU Leuven, Division of Geography and Tourism, Celestijnenlaan $200^{\mathrm{E}}$, B-3001 Heverlee, Belgium

2 School of Water, Energy and Environment, University of Cranfield, Building B 52a, UK

3 Key Laboratory of Mountain Hazards and Earth Surface Processes, Institute of Mountain Hazards and Environment,

Chinese Academy of Sciences, 9\#, Block 4, Renminnanlu Road, Chengdu 610041, China

Abstract: Plant roots can be very effective in stabilizing the soil against concentrated flow erosion. So far, most research on the erosion-reducing potential of plant roots was conducted on loamy soils. However susceptible to incisive erosion processes, at present, no research exists on the effectiveness of plant roots in reducing concentrated flow erosion rates in sandy soils. Therefore, the prime objective of this study was to assess the erosion-reducing potential of both fibrous and tap roots in sandy soils. Furthermore, we investigated potential effects of root diameter, soil texture and dry soil bulk density on the erosion-reducing potential of plant roots. Therefore, flume experiments conducted on sandy soils (this study) were compared with those on sandy loam and silt loam soils (using the same experimental set up). Results showed that plant roots were very efficient in reducing concentrated flow erosion rates in sandy soils compared to root-free bare soils. Furthermore, our results confirmed that fibrous roots were more effective compared to (thick) tap roots. Dry soil bulk density and soil texture also played a significant role. As they were both related to soil cohesion, the results of this study suggested that the effectiveness of plant roots in controlling concentrated flow erosion rates depended on the apparent soil cohesion. The nature of this soil type effect depended on the root-system type: fine root systems were most effective in non-cohesive soils while tap root systems were most effective in cohesive soils. For soils permeated with a given amount of fibrous roots, an increase of soil bulk density seemed to hamper the effectiveness of roots to 
further increase soil cohesion and reduce erosion rates. In soils reinforced by tap root systems, the erosion-reducing power of the roots depended on sand content: the higher the percentage of sand, the smaller the erosion-reducing effect for a given amount of roots. This was attributed to more pronounced vortex erosion around the thicker tap roots in noncohesive soils, increasing soil erosion rates. The results presented in this study could support practitioners to assess the likely erosion-reducing effects of plant root systems based on both root and soil characteristics.

Keywords: Concentrated flow erosion, fibrous root system, tap root system, soil texture, root density, root length density.

\section{Introduction}

An important regulating ecosystem function of vegetation is their potential to control soil erosion processes (e.g. De Groot et al., 2002; Wallace, 2007). As such, plant species are frequently used in bio-engineering projects to improve slope stability and control surface erosion processes (Morgan, 2005; Norris et al., 2008; Stokes et al., 2014). Both above-ground and below-ground parts are important to consider depending on the erosion process dealt with (Gyssels et al., 2005; Vannoppen et al., 2015). Plant roots are very effective in controlling concentrated flow erosion and shallow mass movements by modifying both mechanical and hydrological soil properties (e.g. Simon and Collisson, 2002; Eviner and Chapin, 2003). Furthermore, Erktan et al. (2016) observed a biological effect of plant roots as soil erodibility decreased with different types of plant communities along a plant successional gradient in a gully bed ecosystem. On the other hand, the effects of vegetation cover is more pronounced for splash detachment and interrill erosion (e.g. Zuazo and Pleguezuelo, 2008; Shinohara et al., 2016). Recently, more attention is paid to root traits and their effects on ecosystem services (e.g. Bardgett et al., 2014). Several studies investigated the relation between specific plant traits and their potential to control soil erosion processes (e.g. Gyssels and Poesen, 2003; 
Stokes et al., 2009; Reubens et al., 2007; De Baets et al., 2009; Burylo et al., 2014; Ghestem et al., 2014). The recognition of these beneficial traits can be used to select species to control soil erosion processes (De Baets et al., 2009; Burylo et al., 2014; Bochet et al., 2015). Considering concentrated flow erosion, root density (RD), whether or not in combination with root diameter (D), and root length density (RLD) are the most frequently used root traits to estimate the erosion-reducing potential of plant species and to select the most suitable plant species for controlling soil erosion processes (e.g. De Baets et al., 2009; Pohl et al., 2009; Burylo et al., 2012; Vannoppen et al., 2016). The relationship between the erosion-reducing potential and root density or root length density is most often described by a negatively exponential relationship (Eq. 1; Table 1):

$S D R=e^{-b * R(L) D}$

with SDR the soil detachment ratio expressed as the ratio of the absolute soil detachment rate of a root-permeated soil and a root-free bare soil, $\mathrm{R}(\mathrm{L}) \mathrm{D}$ respectively the root density $(\mathrm{RD}, \mathrm{kg}$ $\mathrm{m}^{-3}$ ) and the root length density ( $\mathrm{RLD}, \mathrm{km} \mathrm{m}^{-3}$ ) and $\mathrm{b}$ a regression parameter. The higher the value of $b$, the more expressed is the erosion-reducing effect of plant roots.

A large number of studies quantified the erosion-reducing effects of plant roots (Vannoppen et al., 2015; Table 1). This erosion-reducing effect depends on root system type (e.g. De Baets et al., 2007; Reubens et al., 2007; Stokes et al., 2009). Given a certain root density, a root system consisting of fibrous roots is hypothesized to have a larger erosion-reducing potential compared to a tap root system due to the larger root-soil contact (Dissmeyer and Foster, 1985). As such root diameter is important to consider as well when using RD as independent variable to predict the erosion-reducing potential of plant roots (e.g. De Baets and Poesen, 2010; Burylo et al., 2012). While most of the reported studies are focused on silt loam soils, 
sand or sandy loam soils are barely studied. However, coarse-textured soils can be very prone to incisive soil erosion processes. Infiltration rates in coarse-grained soils are, in general, higher compared to fine-grained soils (e.g. Moldenhauer and Long, 1964). However, once those soils are saturated or a less permeable surface layer is formed due to sealing and crusting (Poesen, 1986; Valentin, 1991), overland flow will occur, leading to incisive erosion processes on sloping land due to the low soil strength at saturation of coarse-grained soils (Poesen, 1992). This may then lead to intense soil erosion and/or infrastructural damage such as: 1) the formation of large gully systems (e.g. Poesen et al., 2003; Imwangana et al., 2015; Vanmaercke et al., 2016), 2) the destruction of sandy levees causing flood risk (e.g. Vannoppen et al., 2016) and 3) the destruction of earth-banks along roads or at construction sites (e.g. Jägerbrand and Alatalo, 2014).

Soil characteristics are also important to consider when studying concentrated flow erosion rates as they influence the soil erodibility (Knapen et al., 2007). A commonly used variable in the assessment of soil erodibility is soil texture as an increase in sand content generally increases the soil's erodibility (e.g. Elliot et al., 1989; Sheridan et al., 2000a,b). On the other hand, an increased clay fraction decreases the soil's erodibility due to their bonding forces (Smerdon and Beasley, 1959). Poesen (1992) also observed an increasing apparent cohesion with decreasing particle size in saturated soils; i.e. from 1-2 $\mathrm{kPa}$ for sandy soils to 4-6 $\mathrm{kPa}$ for silt loam soils. In addition dry soil bulk density is also important to consider as an increase in soil bulk density decreases soil erosion rates (e.g. Roberts et al., 1998; Zhang et al., 2009; Wang et al., 2014) as soil erodibility decreases (e.g. Knapen et al., 2009; Yu et al., 2014). This is explained by an increase in soil cohesion (e.g. Ghebreiyessus et al., 1994; Bennett et al., 2000; Zhang et al., 2001; Mouazen et al., 2002; Geng et al., 2015). As such, both soil texture and soil bulk density can be used as a proxy for soil cohesion which is important to account for when studying concentrated flow erosion rates. At the moment, no univocal 
conclusion exists concerning the role of soil texture and dry soil bulk density on the erosionreducing effects of plant roots. De Baets and Poesen (2010) observed a negative effect of sand content on soil loss reduction (ranging between $22 \%$ and $56 \%$ ) on the erosion-reducing potential of fibrous plant roots. On the contrary, Vannoppen et al. (2015) stated that sand content (ranging between $6 \%$ and $56 \%$ ) tends to have a positive effect on the erosionreducing effect of plant roots. Therefore, the prime objective of this study is to assess the erosion-reducing potential of two distinct root system types in sandy soils: i.e. a fibrous and a tap root system. We also investigate the effect of root traits (i.e. RD, D, and RLD) and soil characteristics (i.e. soil texture and dry soil bulk density) on the effectiveness of plants on controlling soil erosion rates. This was achieved by comparing flume experiment results for sand (this study) with hydraulic flume results for sandy loam and silt loam soils (De Baets et al., 2006, 2007). As such, this study will contribute to further develop the existing methodology for evaluating potentially useful plant species to control erosion in different soils (Stokes et al., 2014).

\section{Material and methods}

\subsection{Experimental field plots}

Six field plots $($ length $=1.15 \mathrm{~m}$, width $=1.00 \mathrm{~m}$ and soil depth $=0.15 \mathrm{~m}$ ) were installed in spring 2015 nearby the University Campus, Heverlee (Fig. 1). The field plots were filled with a sandy topsoil (94\% sand, $4 \%$ silt and $2 \%$ clay; Table 2 ). Prior to filling, the soil was sieved (1 cm mesh size) in order to break soil aggregates. Three treatments were established consisting of two root-free bare control plots, two plots with grasses having a fibrous root system and two plots with carrots to represent a species with a tap root system. Detailed plant species information is summarised in Table 3. For grasses and carrots, a low and high density plot was installed to obtain differences in root properties (Table, 3; De Baets et al., 2007). Soil 
characteristics for these treatments are summarized in Table 2. Seeds were sown on $14 / 05 / 2015$ and all plots were similarly treated and received the same depth of rain or irrigation water. In total, the plots received $169 \mathrm{~mm}$ precipitation and $50 \mathrm{~mm}$ of water, applied with a watering can, during the first experimental period 14/05/2015 - 28/08/2015. An additional grass and carrot plot were installed on 04/09/2015 with same characteristics (Table 2) in order to provide more root-permeated soil samples. Those additional plots received 128 $\mathrm{mm}$ precipitation and $10 \mathrm{~mm}$ irrigation water during the second experimental period $05 / 9 / 2015-25 / 11 / 2015$. Weeds were manually removed at an early growth stage without disturbing the soil.

\subsection{Sampling procedure}

Soil samples were collected every week starting 6 weeks and 3 weeks after sowing for the first and second growth period respectively in order to have a sufficient $R(L) D$ range. Samples were taken during 14 and 8 weeks respectively after starting the first sample collection. A standardized sampling procedure was applied (De Baets et al., 2006). Rootpermeated soil samples were taken by using a metal box $(35.6 \mathrm{~cm}$ long, $8.8 \mathrm{~cm}$ wide and 8.7 cm deep). Thereafter, the above-ground biomass was clipped level with the soil surface and samples were placed in a container with a constant water level at $4.5 \mathrm{~cm}$ below the soil

surface during 8 hours to obtain soil samples at field capacity. Soil samples were then drained for $12 \mathrm{~h}$ before hydraulic flume experiments were conducted. For each sampling day, three additional soil samples were taken for each treatment using steel rings $(8 \mathrm{~cm}$ high, $\varnothing 5 \mathrm{~cm})$. These additional soil samples were treated the same way as the root-permeated soil samples and were used to measure the gravimetric water content and the dry bulk density (Table 2).

\subsection{Hydraulic flume experiments}


Hydraulic flume experiments were conducted using the flume described by Poesen et al. (1999). For a more detailed description of the experiments we refer to De Baets et al. (2006). For each experimental run, the soil surface slope, flow discharge, mean flow velocity, water temperature and sediment concentration were measured. Soil surface slope and runoff discharge could be varied in order to simulate a range of flow shear stresses. The simulated flow shear stresses $(3-30 \mathrm{~Pa})$ are representative for peak flow conditions at the time of rill and gully formation (Poesen et al., 2003). Sediment concentration was measured during $150 \mathrm{~s}$ by collecting all runoff and transported sediments every $15 \mathrm{~s}$ during $5 \mathrm{~s}$ using 101 buckets. The corresponding mean bottom flow shear stress $(\tau, \mathrm{Pa})$ was calculated as:

$\tau=\rho_{w} g R S$

with $\tau(\mathrm{Pa})$ the mean bottom flow shear stress, $\rho_{w}\left(\mathrm{~kg} \mathrm{~m}^{-3}\right)$ the water density, corrected for temperate, $\mathrm{g}\left(\mathrm{m} \mathrm{s}^{-2}\right)$ the acceleration due to gravity, $\mathrm{R}(\mathrm{m})$ the hydraulic radius and $\mathrm{S}$ the soil surface slope (i.e $\sin \alpha$, with $\alpha\left(^{\circ}\right)$ the slope angle). The hydraulic radius was calculated as:

$R=\frac{a \cdot d}{a+2 d}$

with a (m) the flume width (i.e. $0.088 \mathrm{~m}$ ) and $\mathrm{d}(\mathrm{m})$ the flow depth, calculated as:

$d=\frac{q}{u}$ with $q=\frac{Q}{a}$

with $\mathrm{q}\left(\mathrm{m}^{2} \mathrm{~s}^{-1}\right)$ the unit flow discharge, $\mathrm{Q}\left(\mathrm{m}^{3} \mathrm{~s}^{-1}\right)$ the mean flow discharge and $\mathrm{u}\left(\mathrm{m} \mathrm{s}^{-1}\right)$ the mean surface flow velocity. 
Following sediment deposition in the runoff samples, the collected sediments were separated from the water by decantation, oven dried at $105{ }^{\circ} \mathrm{C}$ and weighted to calculate their dry mass $\left(\mathrm{M}_{\mathrm{s}}, \mathrm{kg}\right)$. The absolute soil detachment rate (ASD, $\mathrm{kg} \mathrm{m}^{-2} \mathrm{~s}^{-1}$ ) was calculated using Eq. 5:

$A S D=\frac{M_{S}}{A \cdot t}$

with $\mathrm{M}_{\mathrm{S}}(\mathrm{kg})$ the mean dry mass, $\mathrm{A}\left(\mathrm{m}^{2}\right)$ the surface area of the soil sample (i.e. $\left.0.031 \mathrm{~m}^{2}\right)$ and $\mathrm{t}(\mathrm{s})$ the duration of runoff collection (i.e. $5 \mathrm{~s}$ ). For each experimental run, 10 runoff samples were taken. As ASD varies over time, mean ASD was calculated for each soil sample as an indicator of its erosion susceptibility during concentrated flow. Furthermore, to quantify the effects of plant roots on concentrated flow erosion, the soil detachment ratio (SDR) instead of ASD was calculated (as ASD of root-free bare soil samples may vary over time due to changes in topsoil bulk density):

$S D R=\frac{A S D_{\text {root-permeated soil }}}{A S D_{\text {bare soil }}}$

SDR values may vary between 1 and 0 . Values near 1 indicate that there is almost no soil erosion reduction due to the presence of roots, while values near 0 indicate that soil erosion rates are reduced to negligible levels due to the roots.

\subsection{Root characteristics}

After each flume experiment, all roots of each sample box were separated from the soil by the wet hand washing method (Schuurman and Goedewaagen, 1965). Floating roots were manually removed and the remaining soil and plant roots were washed and sieved using a 0.5 mm sieve by sprinkling water at low pressure. For each soil sample the total dry root mass 
$\left(\mathrm{M}_{\mathrm{D}}, \mathrm{kg}\right)$ and total root length $\left(\mathrm{L}_{\mathrm{R}}, \mathrm{m}\right)$ of the living roots was measured. $\mathrm{M}_{\mathrm{D}}$ was calculated after drying the roots at $60-65{ }^{\circ} \mathrm{C}$ for 48 hours (Smit et al., 2000). Before drying, the root length and root diameter was calculated. For fine roots $(\mathrm{D}<1 \mathrm{~mm})$, the length of a subsample of roots was measured manually which was then oven-dried. By dividing the root length by the dry root mass of this subsample the specific root length $\left(S R L_{D}<1 \mathrm{~mm}, \mathrm{~m} \mathrm{~g}^{-1}\right)$ was calculated:

$S R L_{D<1 \mathrm{~mm}}\left(\mathrm{mg}^{-1}\right)=\frac{M_{D_{-} \text {subsample }}}{L_{R_{-} \text {subsample }}}$

with $M_{D}(g)$ the dry living root mass, $L_{R}(m)$ the length of the living roots. The total root length for fine roots was then calculated by multiplying $\mathrm{M}_{\mathrm{D}}$ for the whole sample with SRL. For tap roots $(\mathrm{D}>1 \mathrm{~mm})$ the root length was measured for every root and summed to calculate the total root length. Root diameter was measured using a digital calliper (precision is $0.01 \mathrm{~mm})$. For fine roots $(\mathrm{D}<1 \mathrm{~mm})$, a mean value of $0.20 \mathrm{~mm}$ was used for root diameter based on a measured subsample of roots. For the carrot roots, root diameter was measured at the top of each carrot root and root diameter was averaged per sample box. Finally, the root density (RD) and root length density (RLD) were calculated as:

$$
\begin{aligned}
& R D\left(k g ~ m^{-3}\right)=\frac{M_{D}}{V} \\
& R L D\left(k \mathrm{~km}^{-3}\right)=\frac{L_{R}}{1000 * V}
\end{aligned}
$$

with $M_{D}(\mathrm{~kg})$ the dry living root mass, $\mathrm{L}_{\mathrm{R}}(\mathrm{m})$ the length of the living roots and $\mathrm{V}\left(\mathrm{m}^{-3}\right)$ the volume of the soil sample (i.e. $0.00273 \mathrm{~m}^{3}$ ). 


\subsection{Data analysis}

A non-linear regression analysis was used to investigate the relationships between RD, RLD and SDR. Therefore an exponential relationship was fit through the data (Eq. 1) as most studies observed a decreasing trend of soil erosion with increasing RD or RLD (Vannoppen et al., 2015; Table 1). For each relationship, the coefficient of determination $\left(\mathrm{R}^{2}\right.$, Legates and McCabe, 1999) and model efficiency (ME, Nash and Sutcliffe, 1970) were calculated to determine the prediction accuracy of the models:

$$
\begin{aligned}
R^{2} & =\left(\frac{\sum_{i=1}^{n}\left(O_{i}-\bar{O}\right)\left(P_{i}-\bar{P}\right)}{\sqrt{\sum_{i=1}^{n}\left(O_{i}-\bar{O}\right)^{2}} \sqrt{\sum_{i=1}^{n}\left(P_{i}-\bar{P}\right)^{2}}}\right)^{2} \\
M E & =1-\left(\frac{\sum_{i=1}^{n}\left(O_{i}-P_{i}\right)^{2}}{\sum_{i=1}^{n}\left(O_{i}-\bar{O}\right)^{2}}\right)
\end{aligned}
$$

with $\mathrm{O}_{\mathrm{i}}$ the observed values, $\bar{O}$ the observed mean, $\mathrm{P}_{\mathrm{i}}$ the predicted values, $\bar{P}$ the predicted mean, $\mathrm{n}$ the number of observations. ME values can range from $-\infty$ to 1 . The closer ME is to 1, the more efficient the model is while negative ME values indicate that the mean observed value is a better predictor to describe the trend compared to the model predictions. To investigate potential root architecture and soil type effects on the erosion-reducing potential of plant roots, the observations for sandy soils (this study) were pooled with observations for sandy loam and silt loam soils made by De Baets et al. (2006, 2007). Root architecture, soil texture and dry soil bulk density were added to the relationship between R(L)D and SDR as an interaction term of R(L)D. Categorical variables (i.e. soil texture class) were included using a dummy variable as interaction term while root diameter $(\mathrm{D}, \mathrm{mm})$, sand content $(\% \mathrm{~S}$, $\%)$ and dry soil bulk density $\left(\mathrm{BD}, \mathrm{g} \mathrm{cm}^{-3}\right.$ ) were included using a continuous variable as interaction term. 


\section{Results}

\subsection{Erosion-reducing potential of tap and fibrous root systems}

\subsubsection{Sandy soils}

Results show that plant roots are very effective in reducing soil erosion rates due to concentrated flow in sandy soils (Fig. 1). For fibrous roots a strong decrease in SDR is observed for RD ranging from 0 to $0.5 \mathrm{~kg} \mathrm{~m}^{-3}$ and for RLD ranging from 0 to $50 \mathrm{~km} \mathrm{~m}^{-3}$. SDR values are below 0.2 for RD and RLD exceeding these values. This indicates that soil detachment rates are reduced to $20 \%$ or less (compared to the erosion rates for root-free bare soil samples) for larger RD and RLD values. Eq. 12 and 13 can be used to estimate the erosion-reducing potential of fibrous roots in sandy soils (Table 4, Fig. 2):

$$
\begin{array}{ll}
S D R=e^{-17.46 * R D} & \left(\mathrm{R}^{2}=0.61, \mathrm{ME}=0.60, \mathrm{n}=54\right) \\
S D R=e^{-0.15 * R L D} & \left(\mathrm{R}^{2}=0.58, \mathrm{ME}=0.56, \mathrm{n}=54\right)
\end{array}
$$

Tap root effects on concentrated flow erosion rates in sandy soils are less pronounced compared to fibrous roots due to a large scatter in the data and the smaller number of observations (Fig. 1). For RD, no clear trend is visible in the data (Fig. 1) due to the large range in root diameter values (i.e. $0.2-17.8 \mathrm{~mm}$; Table 3). For tap roots $<5 \mathrm{~mm}$ in diameter, a strong decrease can be observed which is similar to the observed trend for fibrous roots. However, if root diameter increases, the erosion-reducing effect decreases. The relationship between SDR and RLD has a higher predictive power for tap roots in sandy soils compared to the relationship between SDR and RD. This can be explained because RLD takes into account root architecture information. Smaller roots will contribute more to the total RLD compared to thick tap roots. As a result, only a significant relationship between SDR an RLD was found 
which can be used to estimate the erosion-reducing potential of tap roots in sandy soils (Eq. 14, Table 4).

$S D R=e^{-0.11 * R L D} \quad\left(\mathrm{R}^{2}=0.37, \mathrm{ME}=0.33, \mathrm{n}=17\right)$

\subsubsection{Comparison sandy soils with sandy loam and silt loam soils}

Using both species information and soil texture class, 12 significant relationships could be observed between R(L)D and SDR (Table 4, Fig. 2). For fibrous roots, the largest b-value was observed in sandy soils $(b=17.46)$ followed by silt loam soils $(b=2.63)$ and sandy loam soils $(b=0.87)$. This indicates that fibrous roots are more effective in sandy soils compared to silt loam and sandy loam soils. The explained variance for fibrous roots ranges between $32 \%$ and $80 \%$ and all ME values are positive (Table 4). These relationships can be used to obtain reliable estimates of the erosion-reducing potential of fibrous roots in sandy, sandy loam or silt loam soils.

For tap roots, the largest $b$-value was observed for sandy loam soils $(b=0.70)$ followed by silt loam soils $(b=0.61)$ and sandy soils $(b=0.16)$. This indicates that tap roots are more effective in sandy loam and silt loam soils compared to sandy soils. However, regression results for tap roots are weak with low $\mathrm{R}^{2}$ and $\mathrm{ME}$ values. This could be explained by the large variation in mean root diameter among tap root samples, ranging between 0.2 and 20 mm (Table 3).

\subsection{Interactions between root traits and soil variables}

\subsubsection{Effect of root diameter on soil-type specific root-erosion reduction relationships}

To account for differences in root diameter among the soil samples, root diameter information was added to the model for the different soil texture classes (Table 5). The parameter values 
of the root diameter interaction term with $\mathrm{RD}$ were positive, resulting in a negative effect of increasing root diameter on the erosion-reducing potential of plant roots given a certain amount of roots in the soil. Significant results were only found for the silt loam and sandy loam dataset. Including root diameter yielded better regression results especially for silt loam soils. Therefore, these relationships could be used to reliably estimate the erosion-reducing potential of plant roots if root diameter and soil texture are known. Although no significant relationship was found for $\mathrm{RD}$ and root diameter in sandy topsoils, a negative effect of the root diameter can be visually observed in Fig. 1

When considering the entire dataset for each soil texture class and both fibrous and tap root data, also three significant relationships were found between SDR and RD when taking into account root diameter information as small tap roots act like fibrous roots. When taking all tested samples into account (both fibrous and tap root samples), the highest parameter value for the root diameter interaction term was found for sandy soils (i.e. 0.88) and much lower parameter values for silt loam and sandy loam (i.e. 0.05 and 0.13 respectively). As such, the negative effect of root diameter on the erosion-reducing potential of plant roots is most pronounced in sandy soils.

\subsubsection{Effect of root diameter, sand content and dry soil bulk density on erosion-reducing} potential of fibrous and tap root systems

An attempt was made to build an overall model including continuous variables that take plant and soil information into account. Therefore, root diameter, sand content and dry soil bulk density were used as variables. For fibrous roots, a best fit was found when including sand content and dry soil bulk density as variables. The parameter for sand content is negative (i.e. -0.08), indicating a positive effect on the erosion-reducing effect of fibrous roots. The parameter of the dry soil bulk density is positive (i.e. 4.85), indicating a negative effect on the 
erosion-reducing effect of fibrous roots (Eq. 15). For tap roots, an important root diameter effect was observed (Fig. 1, Table 5). As thin tap roots $<5 \mathrm{~mm}$ act as fibrous roots, these samples were separately analyzed. For thin tap roots, a significant model $(\mathrm{p}<0.01)$ was found taking with significant parameters for root diameter and sand content information (Eq. 16). The results show a positive sand content effect and a negative root diameter effect on the erosion-reducing potential of plant roots. Soil bulk density effects were not significant. For thick tap roots $>5 \mathrm{~mm}$, the only significant relationship was found with root density and root diameter as prediction variables (Eq. 17). Regression results are low here due to the large scatter in the dataset for thick tap root samples. Despite the lack of a significant relationship when including other variables, Spearman correlation analyses showed that there was a significant positive correlation between SDR and D $(0.43, \mathrm{p}<0.05)$ and between SDR and sand content $(0.32, \mathrm{p}<0.1)$ for thick tap roots. This indicates a negative effect of root diameter and sand content on the erosion-reducing effect of thick tap roots.

$$
\begin{aligned}
& \text { Fibrous: } \quad S D R=e^{(-6.80-0.08 * \% S+4.85 * B D) R D} \quad\left(\mathrm{R}^{2}=0.36, \mathrm{ME}=0.30, \mathrm{n}=120\right) \\
& \text { Tap }(<5 \mathrm{~mm}): S D R=e^{(-2.94+1.06 * D-0.05 * \% S) R D} \quad\left(\mathrm{R}^{2}=0.48, \mathrm{ME}=0.45, \mathrm{n}=14\right) \\
& \text { Tap }(>5 \mathrm{~mm}): S D R=e^{(-0.84+0.04 * D) R D} \quad\left(\mathrm{R}^{2}=0.17, \mathrm{ME}=0.09, \mathrm{n}=49\right)
\end{aligned}
$$

with $\% \mathrm{~S}(\%)$ the sand content, $\mathrm{BD}\left(\mathrm{g} \mathrm{cm}^{-3}\right)$ the dry soil bulk density, $\mathrm{RD}\left(\mathrm{kg} \mathrm{m}^{-3}\right)$ the root density and $\mathrm{D}(\mathrm{mm})$ the root diameter.

As such, fibrous roots were most effective in reducing concentrated flow erosion rates in less compacted sandy soils and least effective in compact sandy loam soils. Thick tap roots were equally effective in sandy loam and silt loam soils while least effective in loose sandy soils.

\section{Discussion}


The hydraulic flume results confirm that plant roots and especially fibrous roots are very effective in reducing erosion rates in sandy soils. Several studies already showed that root diameter had a positive effect on soil detachment rates and thus a negative effect on the erosion-reducing potential of plant roots (e.g. Zhou and Shangguan, 2005; De Baets et al., 2007; Reubens et al., 2007; Stokes et al., 2009; De Baets and Poesen, 2010; Burylo et al., 2012; Yu et al., 2014). Our results confirm these findings and show that fibrous root species are more effective in protecting the topsoil against concentrated flow erosion compared to tap root species. The reduction of erosion rates in sandy soils by plant roots was not affected by the magnitude of the applied flow shear stresses (i.e. 3 - $30 \mathrm{~Pa}$ ) which is in accordance to De Baets et al. (2007).

Furthermore, our experimental data revealed an important effect of soil characteristics (i.e. soil texture class, sand content and dry soil bulk density) on the erosion-reducing potential of plant roots. Altogether, erosion rates generally decrease with increased soil cohesion and increase with increased sand content. As sandy soils typically have less cohesion, fibrous roots add root cohesion to such soils, explaining the significant erosion-reducing effects of these roots in sandy soils.

The differences in erosion-reducing effects between thin $(\mathrm{D}<5 \mathrm{~mm})$ and thick $(\mathrm{D}>5 \mathrm{~mm})$ roots resulted from differences in their root system type and root mechanical properties. Fibrous roots increase the cohesion of the topsoil due to their high tensile strength and high root contact area with the soil (e.g. Mao et al., 2012; Zhang et al., 2014; Zhong et al., 2016), whilst the root-soil contact area in thick tap roots and their tensile strength is much weaker (e.g. De Baets et al., 2008a). As such, even a small number of fibrous roots will increase soil cohesion to a larger extent and protect the topsoil against concentrated flow erosion compared to root-free bare topsoils. Another reason to explain the greater erosion-reducing effect of a given amount of roots in sandy soils can be attributed to apparent soil cohesion differences 
between the sandy and loamy soils and to the nature of the erosion-reduction calculations. The ratio between soil detachment rate for root-permeated topsoils and for root-free bare topsoils is smaller for non-cohesive soils. This can be attributed to the generally higher detachment rates for root-free bare non-cohesive soils (i.e. $2.45 \pm 0.43 \mathrm{~kg} \mathrm{~m}^{2} \mathrm{~s}^{-1}$ for sandy soil) compared to root-free bare cohesive soils (i.e. $1.30 \pm 0.37 \mathrm{~kg} \mathrm{~m}^{2} \mathrm{~s}^{-1}$ for sandy loam soil and $0.80 \pm 0.06$ $\mathrm{kg} \mathrm{m}^{2} \mathrm{~s}^{-1}$ for silt loam soil) in this study. As such, the contribution of a given amount of fibrous plant roots to topsoil reinforcement and hence increase of soil cohesion is larger in non-cohesive soils. Another possible explanation may be the difference in soil compaction between the loamy soil (sandy loam was most compact) and the sandy soil (least compact) (Table 2): in loose soils roots act as binding agents for soil particles whilst this is probably minor in already compacted soils.

For a given root density, thick tap roots increase soil cohesion to a lesser extent than fibrous roots due to their smaller contact area and weaker bonding forces (De Baets et al., 2008b). Furthermore, tap roots may form obstacles for runoff by creating flow turbulence that results in vortex erosion around the tap roots (De Baets et al., 2007) that behave similar to embedded rock fragments (Poesen et al., 1994). This study shows that flow scouring around thick tap roots is more pronounced in less cohesive soils (sandy soils), which is similar to flow around bridge piers (Briaud et al., 2001). As such, sandy soils reinforced by (thick) tap roots show a smaller erosion-reducing potential compared to silt loam and sandy loam soils which have a larger apparent cohesion when moist (Poesen, 1992). Also note that the effect of dry soil bulk density on the erosion-reducing potential of plant roots is much stronger compared to the effect of sand content for these soils (Table 5). Therefore, sand content alone cannot be used as a variable to estimate the erosion-reducing potential of plant roots and should be combined with other parameters that are linked to soil cohesion. However, in case of tap roots no clear effect of dry soil bulk density could be observed which may possibly be attributed to the 
larger variability of the experimental data and the smaller number of observations. In order to fully understand the effect of dry soil bulk density on the erosion-reducing effect of (thick) tap roots, more data is needed.

Analysis of reported b-values (see Eq. 1) showed that there exists a large variability in the effectiveness of plant roots in reducing concentrated flow erosion rates (Table 1). This results from differences in both soil (e.g. soil texture, soil bulk density) and plant characteristics (e.g. species, root system type, root diameter). A clear soil type effect could not be detected based on the analysis of b-values reported in literature due to a lack of experimental data for different soil textures. Even for the same soil type (e.g. silt loam soil) Yu et al. (2014) found larger b-values for both fibrous and tap roots for similar soil bulk densities as compared to the b-values for silt loam topsoils observed in this study (Table 1). However, results should be analyzed with care as reference erosion values (i.e. root-free topsoils), which are used to calculate the SDR, can be assessed differently. Whereas Yu et al. (2014) used the initial soil conditions at the beginning of the growing season as reference value, root-free bare topsoil samples were taken as a reference for each sampling period in this study. As such, the bvalues reported by $\mathrm{Yu}$ et al. (2014) reflect both the effects of increasing root biomass and increased apparent soil cohesion due to natural soil compaction over time. Therefore, a standard measurement protocol and additional experimental data are needed for different soil textures, especially for sandy soils or clayey soils with differences in dry soil bulk density, in order to validate the results presented in this study. This would advance the development of a more general model for estimating the effectiveness of plant roots in reducing concentrated flow erosion using easy measureable soil and plant characteristics.

\section{Conclusions}


Plant roots were very effective in reducing concentrated flow erosion rates in sandy soils. New relationships were established between root (length) density and the soil detachment ratio for both fibrous and tap roots. These relationships could be used to estimate the erosionreducing potential of plant roots in sandy soils. Comparison of these results with those for sandy loam and silt loam soils revealed a significant effect of root diameter, sand content and dry soil bulk density on the effectiveness of plant roots in reducing soil erosion rates during concentrated flow. The effectiveness of fibrous roots in reducing concentrated flow erosion rates was positively correlated with sand content and negatively to dry soil bulk density. The potential of small tap roots $(\mathrm{D}<5 \mathrm{~mm}$ ) to reduce concentrated flow erosion rates was positively related to sand content and negatively to root diameter whereas the erosionreducing potential for thick tap roots $(\mathrm{D}>5 \mathrm{~mm}$ ) was negatively related to sand content and root diameter. As such, the erosion-reducing potential of plant roots was clearly influenced by soil texture and soil cohesion: fibrous roots and thin tap roots were more effective in less cohesive soils (with a higher sand content and/or lower dry soil bulk density) while thick tap roots were more effective in more cohesive soils (with a lower sand content). The latter can be attributed to more pronounced vortex erosion around the thicker tap roots in non-cohesive soils. The results presented in this study could support practitioners to assess the likely erosion-reducing effects of plant species based on root and soil characteristics.

\section{Acknowledgements}

Financial support by KU Leuven for this research is acknowledged. Lore Fondu, Christophe Coeck, Daan Raymaekers and Lore De Winter are thanked for their assistance with the hydraulic flume experiments. We also thank the anonymous reviewers for their constructive comments. 


\section{References}

Bardgett, R.D., Mommer, L., De Vries, F.T., 2014. Going underground: root traits as drivers of ecosystem processes. Trends in Ecology \& Evolution 29(12): 692-699. DOI: 10.1016/j.tree.2014.10.006.

Bennett, S.J., Casali, J., Robinson, K.M., Kadavy, K.C., 2000. Characteristics of actively eroding ephemeral gullies in an experimental channel. Transactions of the ASAE 43(3): 641-649. DOI: 10.13031/2013.2745.

Bochet, E., Román, A., De Baets, S., Poesen, J., 2012. Root characteristics of two Mediterranean shrubs and their erosion-reducing potential during concentrated flow. $3^{\text {rd }}$ International Conference on Soil Bio- and Eco-Engineering. The Use of Vegetation to Improve Soil Stability. University of British Columbia, Vancouver, Canada, 23-27 July 2012, p. 19 (Poster, Book of Abstracts).

Bochet, E., García-Fayos, P, 2015. Identifying plant traits: a key aspect for species selection in restoration of eroded roadsides in semiarid environments. Ecological Engineering 83: 444-451. DOI: 10.1016/j.ecoleng.2015.06.019.

Briaud, J., Ting, F., Chen, H., Cao, Y., Han, S., Kwak, K., 2001. Erosion function apparatus for scour rate predictions. Journal of Geotechnical and Geoenvironmental Engineering 10: 105-113. DOI: 10.1061/(ASCE)1090-0241(2001)127:2(105).

Bunte, K., Poesen, J., 1994. Effects of rock fragment size and cover on overland flow hydraulics, local turbulence and sediment yield on an erodible soil surface. Earth Surface Processes and Landforms 19: 115-135. DOI: 10.1002/esp.3290190204.

Burylo, M., Hudek, C., Rey, F., 2012. Plant root traits affecting the resistance of soils to concentrated flow erosion. Earth Surface Processes and Landforms 37: 1463-1470. DOI: 10.1002/esp.3248. 
Burylo, M., Dutoit, T., Rey, F., 2014. Species traits as practical tools for ecological restoration of marly eroded lands. Restoration Ecology 22(5): 633-640. DOI: 10.1111/rec.12113.

Chau, N.L., Chu, L.M., 2017. Fern cover and the importance of plant traits in reducing erosion on steep soil slopes. Catena 151: 98-106. DOI: 10.1016/j.catena.2016.12.016.

De Baets, S., Poesen, J., Gyssels, G., Knapen, A. 2006. Effects of grass roots on the erodibility of topsoils during concentrated flow. Geomorphology 79: 54-67. DOI: 10.1016/j.geomorph.2005.10.002.

De Baets, S., Poesen, J., Knapen, A., Galindo, P., 2007. Impact of root architecture on the erosion-reducing potential of roots during concentrated flow. Earth Surface Processes and Landforms 32: 1323-1345. DOI: 10.1002/esp.1470.

De Baets, S., Poesen, H., Reubens, B., Wemans, K., De Baerdemaeker, J., Muys, B., 2008a. Root tensile strength and root distribution of typical Mediterranean plant species and their contribution to soil shear strength. Plant and Soil 305: 207-226. DOI: 10.1007/s11104008-9553-0.

De Baets, S., Torri, D., Poesen, J., Salvador, M.P., Meersmans, J., 2008b. Modelling increased soil cohesion due to roots with EUROSEM. Earth Surface Processes and Landforms 33: 1948-1963. DOI: 10.1002/esp.1647.

De Baets, S., Poesen, J., Reubens, B., Muys, B., De Baerdemaeker, J., Meersmans, J., 2009. Methodological framework to select plant species for controlling rill and gully erosion: application to a Mediterranean ecosystem. Earth Surface Processes and Landforms 34: 1374-1392. DOI: 10.1002/esp.1826.

De Baets, S., Poesen, J., 2010. Empirical models for predicting the erosion-reducing effects of plant roots during concentrated flow erosion. Geomorphology 118: 425-432. DOI: 10.1016/j.geomorph.2010.02.011. 
De Baets, S., Poesen, J., Meersmans, J., Serlet, L., 2011. Cover crops and their erosionreducing effects during concentrated flow. Catena 85: 237-244. DOI: 10.1016/j.catena.2011.01.009.

De Groot, R.S., Wilson, M.A., Boumans, R.M.J., 2002. A typology for the classification, description and valuation of ecosystem functions, goods and services. Ecological economics 41: 393-408. DOI: 10.1016/S0921-8009(02)00089-7.

Dissmeyer, G.E., Foster, G.R., 1985. Modifying the universal soil loss equation for forest land. In El-Swaify, S.A., Moldenhauer, W.C., Lo, A. (Eds.), Soil erosion and conservation, Ankeny, IA: Soil Conservation Society of America, 480-495.

Elliot, W.J., Liebenow, A.M., Laflen, J.M., Kohl, K.D., 1989. A compendium of soil erodibility data from WEPP cropland soil field erodibility experiments 1987-1988. NSERL Rpt. No. 3. Ohio State University and Natural Soil Erosion Research Laboratory, Agricultural Research Service, U.S. Department of Agriculture, W. Lafayette, Indiana.

Erktan, A., Cécillon, L., Graf, F., Roumet, C., Legout, C., Rey, F., 2016. Increase in soil aggregate stability along a Mediterranean successional gradient in severely eroded gully bed ecosystems: combined effects of soil, root traits and plant community characteristics. Plant and Soil 398: 121-137. DOI; 10.1007/s11104-015-2647-6.

Eviner, V.T., Chapin, F.S., 2003. Functional matrix: A conceptual framework for predicting multiple plant effects on ecosystem processes. Annual Review of Ecology, Evolution and Systematics 34: 455-485. DOI: 10.1146/annurev.ecolsys.34.011802.132342.

Geng, R., Zhang, G, Li, Z., Wang, H., 2015. Spatial variation in soil resistance to flowing water erosion along a regional transect in the Loess Plateau. Earth Surface Processes and Landforms 40: 2049-2058. DOI: 10.1002/esp.3779. 
Ghebreiyessus, Y.T., Gantzer, C.J., Alberts, E.E., Lentz, R.W., 1994. Soil erosion by concentrated flow: shear stress and bulk density. Transactions of the ASAE 37: 1791-1797. DOI: $10.13031 / 2013.28268$.

Ghestem, M., Cao, K., Ma, W., Rowe, N., Leclerc, R., Gadenne, C., Stokes, A., 2014. A framework for identifying plant species to be used as 'ecological engineers' for fixing soil on unstable slopes. PLoS ONE 9(8):e95876. DOI: 10.1371/journal.pone.0095873.

Gyssels, G., Poesen, J., 2003. The importance of plant root characteristics in controlling concentrated flow erosion rates. Earth Surface Processes and Landforms 28(4): 371-384. DOI: $10.1002 /$ esp.447.

Gyssels, G., Poesen, J., Bochet, E., Li, Y., 2005. Impact of plant root characteristics on the resistance of soils to erosion by water: a review. Progress in Physical Geography 29(2):189-217. DOI: 10.1191/0309133305pp443ra.

Gyssels, G., Poesen, J., Liu, G., Van Dessel, W., Knapen, A., De Baets, S., 2006. Effects of cereal roots on detachment rates of single- and double-drilled topsoils during concentrated flow. European Journal of Soil Science 57: 381-391. DOI: 10.1111/j.13652389.2005.00749.x.

Imwangana, FM., Vandecasteele, I., Trefois, P., Ozer, P. Moeyersons, J., 2015. The origin and control of mega-gullies in Kinshasa (D.R. Congo). Catena 125: 38-49. DOI: 10.1016/j.catena.2014.09.019.

Jägerbrand, A.K., Alatalo, J.M., 2014. Native roadside vegetation that enhances soil erosion control in Boreal Scandinavia. Environments 1: 31-41. DOI: 10.3390/environments1010031.

Knapen, A., Poesen, J., Govers, G., Gyssels, G., Nachtergaele, J., 2007. Resistance of soils to concentrated flow erosion: A review. Earth-Science Reviews 80: 75-109. DOI: 10.1016/j.earscirev.2006.08.001. 
Legates, DR., McCabe, G.J; 1999. Evaluating the use of "goodness-of-fit" measures in hydrologic and hydroclimatic model validation. Water Resources Research 35: 233-241. DOI: 10.1029/1998WR900018.

Léonard, J., Richard, G., 2004. Estimation of runoff critical shear stress for soil erosion from soil shear strength. Catena 57: 233-249. DOI: 10.1016/j.catena.2003.11.007.

Li, Q., Liu, G., Xu, M., Zhang, Z., 2014. Relationship of soil erodibility, soil physical properties and root biomass with the age of Caragana korshinskii Kom. Plantations on the hilly Loes Plateau, China. Arid Land Research and Management 28: 311-324. DOI: 10.1080/15324982.2013.855957.

Li, Z., Zhang, G., Geng, R., Wang, H., Zhang, X., 2015. Land use impacts on soil detachment capacity by overland flow in the Loess Plateau, China. Catena 124: 9-17. DOI:10.1016/j.catena.2014.08.019.

Liu, G., Huang, C., Hickman, M.V., 2005. Effects of plant roots on soil detachment by runoff. (Unpublished manuscript).

Liu, Y., Hu, J., Wang, T., Cai, C., Li, Z., Zhang, Y., 2016. Effects of vegetation cover and road-concentrated flow on hillslope erosion in rainfall and scouring simulation tests in the Three Gorges Reservoir Area, China. Catena 136: 108-117. DOI: 10.1016/j.catena.2015.06.006.

Mamo, M., Bubenzer, G.D., 2001a. Detachment rate, soil erodibility, and soil strength as influenced by living plant roots. Part I: laboratory study. Transactions of the American Society of Agricultural Engineers 44: 1167-1174.

Mamo, M., Bubenzer, G.D., 2001b. Detachment rate, soil erodibility, and soil strength as influenced by living plant roots. Part II: field study. Transactions of the American Society of Agricultural Engineers 44: 1175-1181. 
Mao, Z., Saint-André, L., Genet, M., Mine, F., Jourdan, C., Rey, H., Courbaud, B., Stokes, A., 2012. Engineering ecological protection against landslides in diverse mountain forests : Choosing cohesion models. Ecological Engineering 45: 55-69. DOI: 10.1016/j.ecoleng.2011.03.026.

Moldenhauer, W.C., Long, D.C., 1964. Influence of rainfall energy on soil loss and infiltration rates: I. Effect over a range of texture. Soil Science Society of America Journal 28: 813-817. DOI: 10.2136/sssaj1964.03615995002800060036x.

Morgan, R.P.C. (2005). Soil erosion \& Conservation. Third edition. Blackwell Publishing, Oxford, pp. 316.

Mouazem, A.M., Ramon, H., De Baerdemaeker, J., 2002. Effects of bulk density and moisture content on selected mechanical properties of sandy loam soil. Biosystems Engineering 83(2): 217-224. DOI: 10.1016/S1537-5110(02)00149-6.

Nash, J.E., Sutcliffe, J.V., 1970. River flow forecasting through conceptual models part 1 - a discussion of principles. Journal of Hydrology 10: 282-290. DOI: 10.1016/00221694(70)90255-6.

Norris, J.E., Stokes, A., Mickovski, S.B., Cammeraat, E., van Beek, R., Nicoll, B.C., Achim, A. (Eds.) 2008. Slope stability and erosion control: ecotechnological solutions. Springer, Dordrecht, the Netherlands, pp. 290.

Poesen, J., 1986. Surface sealing as influenced by slope angle and position of simulated stones in the top layer of loose sediments. Earth Surface Processes and Landforms 11: 110. DOI: 10.1002/esp.3290110103.

Poesen, J., 1992. Mechanisms of overland-flow generation and sediment production on loamy and sandy soils with and without rock fragments: Part II. In Parsons, A.J., Abrahams, A.D. (eds.), 1992. Overland Flow hydraulics and erosion mechanics. UCL Press, London. 
Poesen, J., Nachtergaele, J., Verstraeten, G., Valentin, C., 2003. Gully erosion and environmental change: importance and research needs. Catena 50: 91-133. DOI: 10.1016/S0341-8162(02)00143-1.

Poesen, J., 1992. Mechanisms of overland-flow generation and sediment production on loamy and sandy soils with and without rock fragments. In Parsons, A.J., Abrahams, A.D. (eds.), 1992. Overland flow hydraulics and erosion mechanics. UCL Press, London.

Poesen, J., Torri, D., Bunte, K., 1994. Effects of rock fragments on soil erosion by water at different spatial scales: a review. Catena 23, 141-166. DOI: 10.1016/0341-8162(94)900582.

Poesen, J., De Luna, E., Franca, A., Nachtergaele, J., Govers, G., 1999. Concentrated flow erosion rates as affected by rock fragments cover and initial soil moisture content. Catena 36: 315-329. DOI: 10.1016/S0341-8162(99)00044-2.

Pohl, M., Alig, D., Körner, C., Rixen, C., 2009. Higher plant diversity enhances soil stability in disturbed alpine ecosystems. Plant and Soil 324: 91-102. DOI: 10.1007/s11104-0099906-3

Reubens, B., Poesen, J., Danjon, F., Geudens, G. Muys, B., 2007. The role of fine and coarse roots in shallow slope stability and soil erosion with a focus on root system architecture: a review. Trees 21: 385-402. DOI: 10.1007/s00468-007-0132-4.

Roberts, J., Jepsen, R., Gotthard, D., Lick, W., 1998. Effects of particle size and bulk density on erosion of quartz particles. Journal of hydraulic engineering 124(12): 1261-1267. DOI: 10.1061/(ASCE)0733-9429(1998)124:12(1261)

Schuurman, J.J., Goedewaagen, M.A.J., 1965. Methods for the examination of root systems and roots. Center for Agricultural Publications and Documentation, Wageningen. 
Shit, P.K., Maiti, R., 2012. Effects of plant root density on the erodibility of lateritic topsoil by simulated flume experiment. International Journal of Forest, Soil and Erosion 2: 137142.

Simon, A., Collison, A.J.C., 2002. Quantifying the mechanical and hydrological effects of riparian vegetation on streambank stability. Earth Surface Processes and Landforms 27: 527-546. DOI: 10.1002/esp.325.

Sheridan, G.J., So, H.B., Loch, R.J., Pocknee, C., Walker, C.M., 2000a. Use of laboratoryscale rill and interrill erodibility measurements for the prediction of hillslope-scale erosion on rehabilitated coal mine soils and overburdens. Australian Journal of Soil Research 38: 285-297. DOI: 10.1071/SR99039.

Sheridan, G.J., So, H.B., Loch, R.J., Walker, C.M., 2000b. Estimation of erosion model erodibility parameters from media properties. Australian Journal of Soil Research 38: 256284. DOI: $10.1071 /$ SR99041.

Shinohara, Y., Otani, S., Kubota, T., Otsuki, K., Nanko, K. (2016). Effects of plant roots on the soil erosion rate under simulated rainfall with high kinetic energy. Hydrological Sciences Journal 61: 2435-2442. DOI: 10.1080/02626667.2015.1112904.

Shit, P.K., Maiti, R., 2012. Effects of plant root density on the erodibility of lateritic topsoil by simulated flume experiment. International Journal of Forest, Soil and Erosion 2(3):137-142.

Smit, A.L., Bengough, A.G., Engels, C., van Noordwijk, M., Pellerin, S., van de Geijn, S.C., 2000. Root methods, a handbook. Springer-Verlag, Heidelberg, pp. 587.

Stokes, A., Atger, C., Bengough, A.G., Fourcaud, T., Sidle, R.C., 2009. Desirable plant root traits for protecting natural and engineered slopes against landslides. Plant and Soil 324: 130. DOI: $10.1007 / \mathrm{s} 11104-009-0159-y$. 
Stokes, A., Douglas, G.B., Fourcaud, T., Giadrossich, F., Gillies, C., Hubble, T., Kim, J.H., Loades, K.W., Mao, Z., McIvor, I.R., Mickovski, S.B., Mitchell, S., Osman, N., Philips, C., Poesen, J., Polster, D., Preti, F., Raymond, P., Rey, F., Schwarz, F., Walker, L.R. 2014. Ecological mitigation of hillslope instability: ten key issues facing researchers and practitioners. Plant and Soil 377: 1-23. DOI: 10.1007/s11104-014-2044-6.

Valentin, C., 1991. Surface crusting in two alluvial soils of northen Niger. Geoderma 48: 201222. DOI: 10.1016/0016-7061(91)90045-U.

Vanmaercke, M., Poesen, J., Van Mele, B., Demuzere, M., Bruynseels, A., Golosov, V., Rodrigues Bezerra, J.F., Bolysov, S., Dvinskih, A., Frankl, A., Fuseina, Y., Teixeira Guerra, A.J., Haregeweyn, N., Ionita, I., Makanzu Imwangana, F., Moeyersons, J., Moshe, I., Nazari Samani, A., Niacsu, L., Nyssen, J., Otsuki, Y., Radoane, M., Rysin, I., Ryzhov, Y.V., Yermolaev, O., 2016. How fast do gully headcuts retreat? Earth-Science Reviews 154: 336-355. DOI: 10.1016/j.earscirev.2016.01.009.

Vannoppen, W., Vanmaercke, M., De Baets, S., Poesen, J. 2015. A review of the mechanical effects of plant roots on concentrated flow erosion rates. Earth-Science Reviews 150: 666678. DOI: 10.10016/j.earscirev.2015.08.011.

Vannoppen, W., Poesen, J., Peeters, P., De Baets, S., Vandevoorde, B., 2016. Root properties of vegetation communities and their impact on the erosion resistance of river dikes. Earth Surface Processes and Landforms 41: 2038-2046. DOI: 10.1002/esp.3970.

Wallace, K.J., 2007. Classification of ecosystem services: problems and solutions. Biological conservation 139: 235-246. DOI: 10.1016/j.biocon.2007.07.015.

Wang, B., Zhang, G., Shi, Y., Zhang, Ren, Z., Zhu, L., 2013. Effect of natural restoration time of abandoned farmland on soil detachment by overland flow in the Loess Plateau of China. Earth Surface Processes and Landforms 38: 1725-1734. DOI: 10.1002/esp.3459. 
Wang, B., Zhang, G., Shi, Y., Zhang, X., 2014. Soil detachment by overland flow under different vegetation restoration models in the Loess Plateau of China. Catena 116: 51-59. DOI: 10.1016/j.catena.2013.12.010.

Yu, Y., Zhang, G., Geng, R., Sun, L., 2014. Temporal variation in soil detachment capacity by overland flow under four typical crops in the Loess Plateau of China. Biosystems Engineering 122: 139-148. DOI: 10.1016/j.biosystemseng.2014.04.004.

Zhang, B., Zhao, Q.G., Horn, R., Baumgartl, T., 2001. Shear strength of surface soil as affected by soil bulk density and soil water content. Soil \& Tillage Research 59: 97-106. DOI: 10.1016/S0167-1987(01)00163-5.

Zhang, G., Tang, M., Zhang, X., 2009. Temporal variation in soil detachment under different land uses in the Loess Plateau of China. Earth Surface Processes and Landforms 34: 13021309. DOI: 10.1002/esp.1827.

Zhang, G., Tang, K., Ren, Z., Zhang, X., 2013. Impact of grass root mass density on soil detachment capacity by concentrated flow on steep slopes. Transactions of the American Society of Agricultural and Biological Engineers 56: 927-934.

Zhang, C., Chen, L., Jiang, J., 2014. Why fine tree roots are stronger than thicker roots : The role of cellulose and lignin in relation to slope stability. Geomorphology 206: 196-202. DOI: 10.1016/j.geomorph.2013.09.024.

Zhao, C., Gao, J., Huang, Y., Wang, G., Xu, Z., 2016. The contribution of Astralagus adsurgens roots and canopy to water erosion control in the water-wind crisscrossed erosion region of the Loess Plateau, China. Land degradation \& Development, DOI: $10.1002 / 1 d r .2508$

Zhong, R., He, X., Bao, Y., Tang, Q, Gao, J., Yan, D., Wang, M., Li, Y., 2016. Estimation of soil reinforcement by the roots of four post-dam prevailing grass species in the riparian 
zone of Three Gorges Reservoir, China. Journal of Mountain Science 13: 508-521. DOI: $10.1007 / \mathrm{s} 11629-014-3397-2$.

Zhou, Z., Shangguan, Z., 2005. Soil anti-scourability enhanced by plant roots. Journal of Integrative Plant Biology 47: 676-682. DOI: 10.1111/j.1744-7909.2005.00067.x

Zuazo, V.H., Pleguezuelo, C.R.R., 2008. Soil-erosion and runoff prevention by plant covers. A review. Agronomy for Sustainable Development 28: 65-86. DOI: 10.1051/agro:2007062. 
Fibrous roots

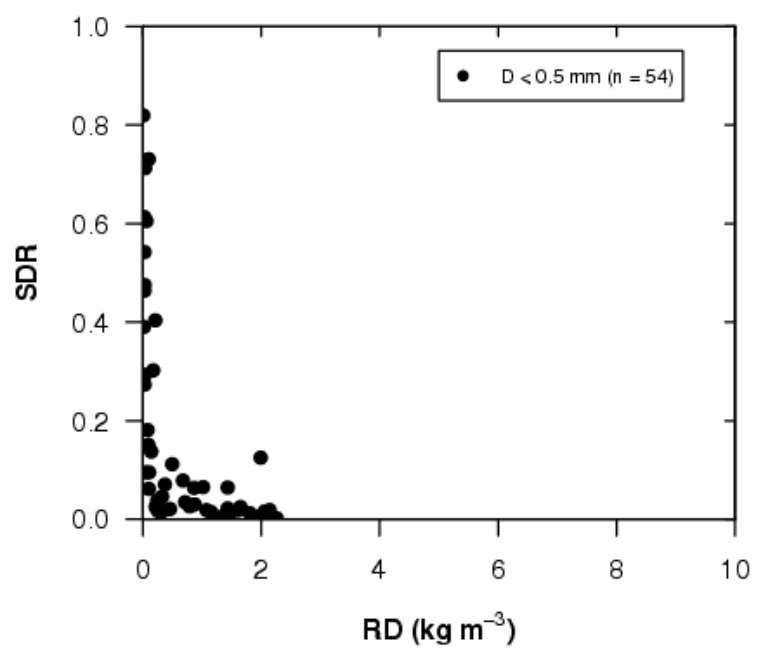

Tap roots

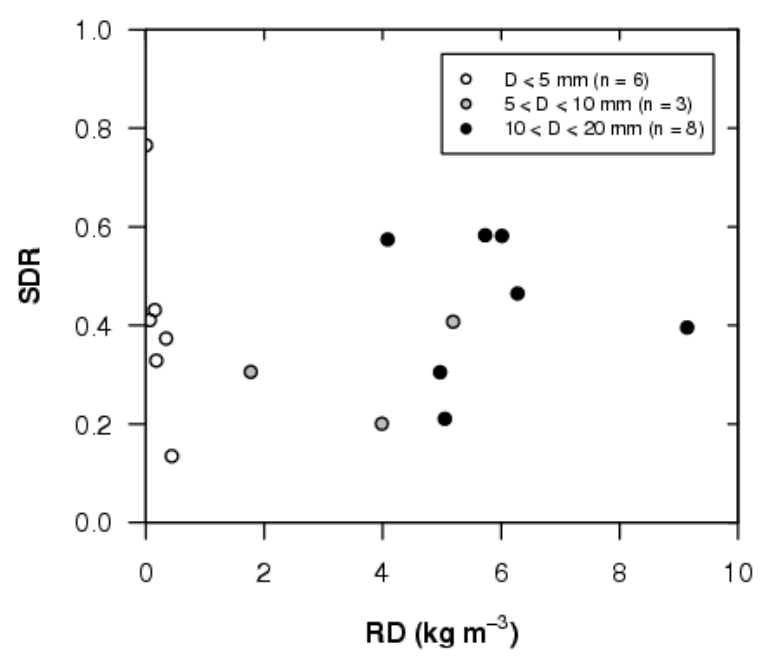

Fibrous roots

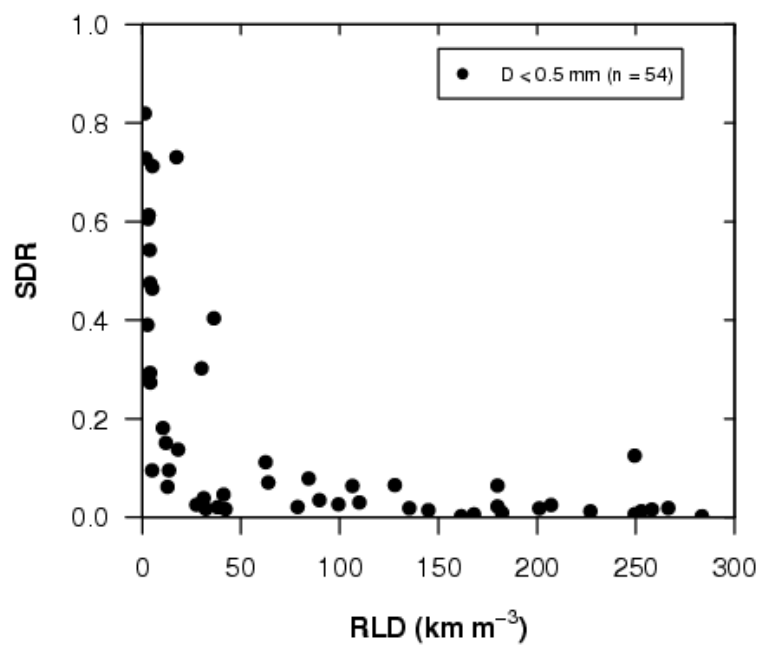

Tap roots

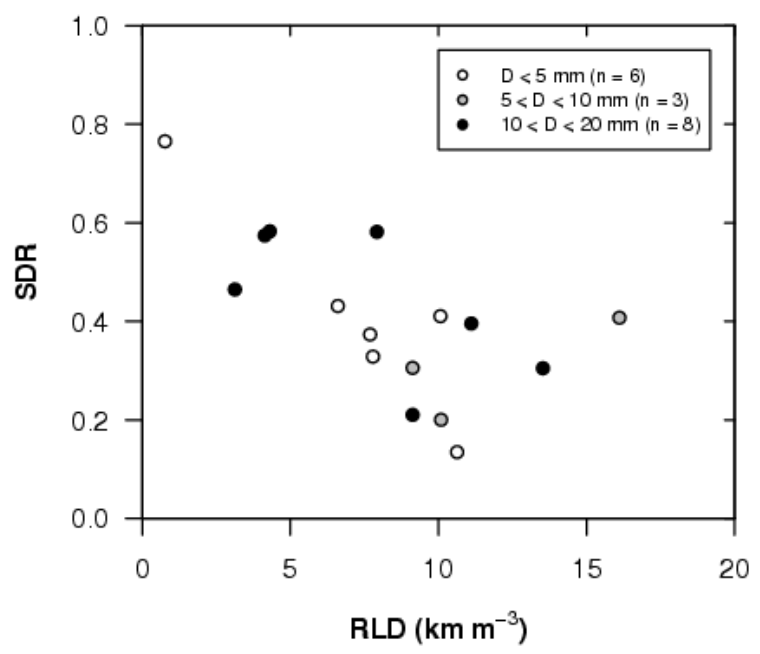

Fig. 1. Soil detachment ratio (SDR) as a function of root density (RD) and root length density (RLD) for grasses with fibrous roots and carrots with tap roots growing in a sandy topsoil. For carrots, samples were grouped into three classes based on their mean root diameter. 
Fibrous roots

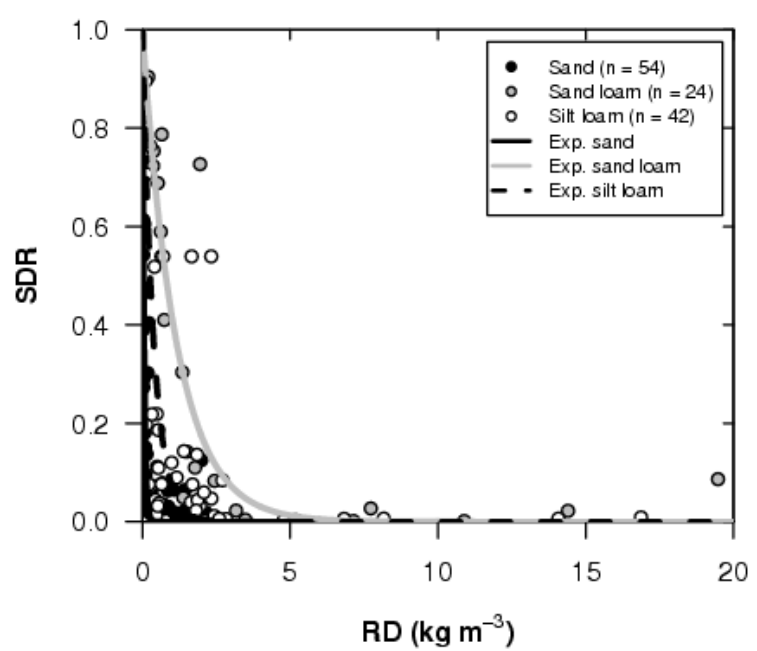

Tap roots

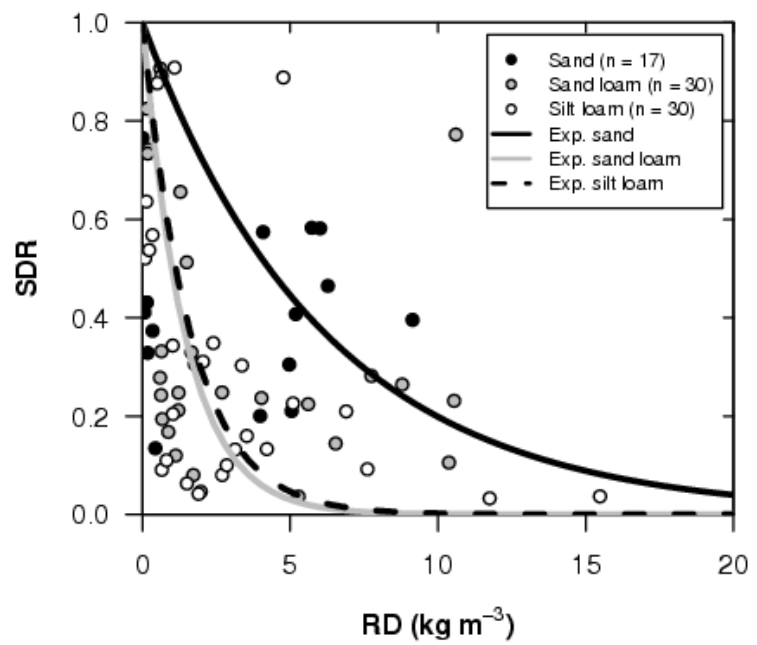

Fibrous roots

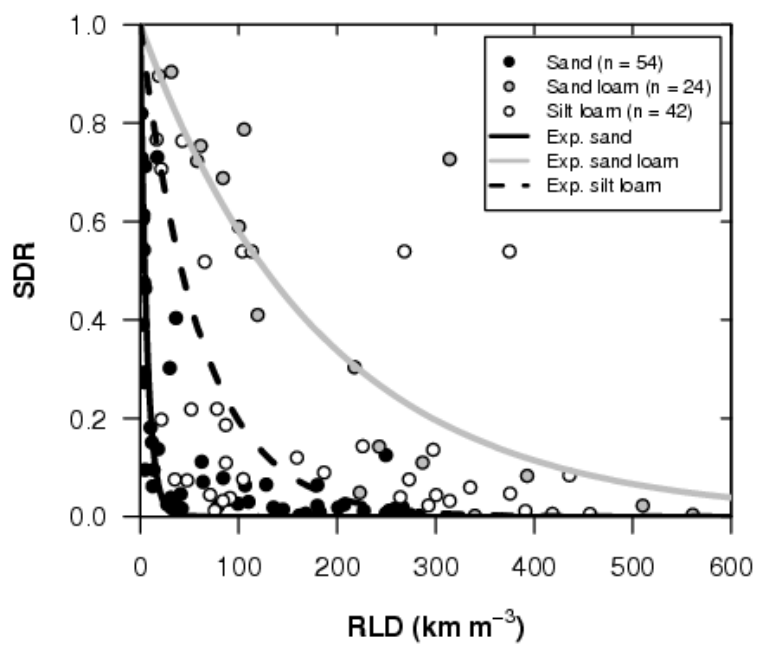

Tap roots

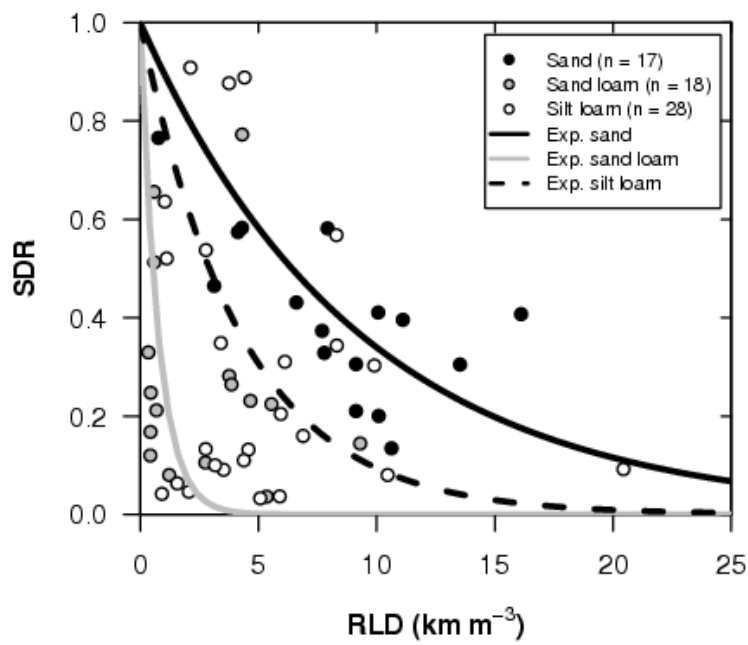

Fig. 2. Soil detachment ratio (SDR) as a function of root density (RD) and root length density (RLD) for grasses with fibrous roots and carrots with tap roots growing in sandy, sandy loam and silt loam topsoils. 
Table 1: Overview of empirical studies reporting an exponential relationship between soil detachment ratio (SDR) and root density (RD) or root length density (RLD), i.e. $S D R=(a) * e^{-b * R(L) D}(\mathrm{Eq} .1)$ for different soil textures.

\begin{tabular}{|c|c|c|c|c|c|c|c|c|c|}
\hline Soil texture & $\begin{array}{l}\text { Root } \\
\text { type }\end{array}$ & $\begin{array}{c}\text { BD } \\
\left(\mathrm{g} \mathrm{cm}^{-3}\right)\end{array}$ & $\mathbf{b}$ & $\mathbf{R}^{2}$ & $\bar{n}$ & $\begin{array}{c}\text { RD range } \\
\left(\mathrm{kg} \mathrm{m}^{-3}\right)\end{array}$ & $\begin{array}{c}\text { RLD range } \\
\left(\mathrm{km} \mathrm{m}^{-3}\right)\end{array}$ & Plant species & Source \\
\hline$\overline{\text { Sand }}$ & Mixture* & $\overline{\mathrm{NA}}$ & 0.24 & 0.51 & 31 & $0.33-13.72$ & $\overline{\mathrm{NA}}$ & T. vulgaris; G. scorpius & Bochet et al., 2012 \\
\hline Sandy loam & Rhizoid & 1.56 & 1.98 & 0.73 & 10 & $0.20-4.25$ & NA & $\begin{array}{l}\text { B. orientale, C., parasiticus, D., pedata, } N \text {. auriculata, } \\
\text { P. vitata }\end{array}$ & Chau and Chu, 2017 \\
\hline Sandy loam & Fibrous & $0.82-1.43$ & 0.80 & 0.74 & 20 & $0.31-7.14$ & NA & A. aciculate, E. cynosuroides, P. maxima, S. munja. & Shit and Maiti (2012) \\
\hline Sandy / silt loam & Mixture & $0.90-1.44$ & 1.75 & 0.51 & 83 & $0.00-4.00$ & NA & P. paucifolia, S. bungeana, Z. mays, R. pseudoacacia & Geng et al., 2015 \\
\hline Silt loam & Fibrous & $1.25-1.30$ & 5.97 & 0.89 & 7 & $0.43-2.25$ & NA & L. perenne, A. sativa, S. cereale & De Baets et al., 2011 \\
\hline Silt loam & Fibrous & $1.25-1.30$ & 0.26 & 0.89 & 7 & NA & $9.86-28.29$ & L. perenne, A. sativa, S. cereale & De Baets et al., 2011 \\
\hline Silt loam & Tap & $1.25-1.30$ & 1.32 & 0.20 & 22 & $0.02-1.73$ & NA & S. alba, P. tanacetifolia, $R$. sativus & De Baets et al., 2011 \\
\hline Silt loam & Tap & $1.25-1.30$ & 0.18 & 0.21 & 22 & NA & $0.79-44.98$ & S. alba, P. tanacetifolia, $R$. sativus & De Baets et al., 2011 \\
\hline Silt loam & Mixture & $1.25-1.30$ & 1.93 & 0.10 & 29 & $0.02-2.25$ & NA & $\begin{array}{l}\text { L. perenne, A. sativa, S. cereale, S. alba, P. tanacetifolia, } \\
\text { R. sativus }\end{array}$ & De Baets et al., 2011 \\
\hline Silt loam & Mixture & $1.25-1.30$ & 0.19 & 0.20 & 29 & NA & $0.79-44.98$ & $\begin{array}{l}\text { L. perenne, A. sativa, S. cereale, S. alba, P. tanacetifolia, } \\
\text { R. sativus }\end{array}$ & De Baets et al., 2011 \\
\hline Silt loam & Mixture & 1.30 & 2.25 & 0.59 & 58 & $0.01-1.83$ & NA & H. vulgare, G. $\max$ & Gyssels et al., (2006) \\
\hline Silt loam & Fibrous & $1.21-1.28$ & 6.85 & 0.76 & 26 & $0.04-0.62$ & NA & S. bungeana, B. Ischaemum & $\mathrm{Li}$ and $\mathrm{Li}(2011)$ \\
\hline Silt loam & Mixture & $0.91-1.22$ & 0.29 & 0.87 & 5 & $1.76-14.29$ & NA & C. Korshinskii Kom. Mixtured with grasses & Li et al., 2014 \\
\hline Silt loam & Mixture & $1.2-1.5$ & 4.63 & 0.43 & 125 & $0.15-7.41$ & NA & Grassland, orchard, wasteland, shrub land, woodland & Li et al., 2015 \\
\hline Silt loam & Fibrous & 1.3 & 0.03 & 0.93 & 15 & NA & $21.20-119.50$ & H. vulgare & Liu et al., 2005 \\
\hline Silt loam & Tap & 1.3 & 0.02 & 0.46 & 13 & NA & $4.30-88.50$ & G. $\max$ & Liu et al., 2005 \\
\hline Silt loam & Mixture & 1.3 & 0.07 & 0.60 & 30 & NA & $0.50-44.37$ & H. vulgare, G. $\max$ & Liu et al., 2005 \\
\hline Silt loam & Mixture & 1.12 & 0.03 & 0.84 & 30 & NA & $0.15-24.21$ & M. sativa, L. perenne & Mamo and Bubenzer (2001a) \\
\hline Silt loam & Tap & NA & 0.23 & 0.54 & 15 & NA & $2.97-6.89$ & G. $\max$ & Mamo and Bubenzer (2001b) \\
\hline Silt loam & Mixture & $1.19-1.27$ & 6.79 & 0.92 & 36 & $0.31-7.86$ & NA & G. max, A. capillaries, A. sacrorum, S. bungeana & Wang et al., 2013 \\
\hline Silt loam & Mixture & $1.19-1.28$ & 0.12 & 0.23 & 30 & $5.10-22.46$ & NA & $\begin{array}{l}\text { G. max, S. bungeana, A. sacrorum, C. lanceolata, A. } \\
\text { giraldii }\end{array}$ & Wang et al., 2014 \\
\hline Silt loam & Fibrous & 1.13 & 1.70 & 0.72 & 7 & $0.01-1.04$ & NA & Z. mays & Yu et al., 2014 \\
\hline Silt loam & Fibrous & 1.13 & 16.15 & 0.89 & 7 & $0.01-0.14$ & NA & P. miliaceum & Yu et al., 2014 \\
\hline Silt loam & Tap & 1.09 & 6.20 & 0.50 & 7 & $0.02-0.21$ & NA & G. $\max$ & Yu et al., 2014 \\
\hline Silt loam & Tap & 1.09 & 4.01 & 0.26 & 7 & $0.00-0.15$ & NA & S. tuberosum & Yu et al., 2014 \\
\hline Loam & Mixture & $1.31-1.39$ & 0.84 & 0.73 & 27 & $0.76-4.60$ & NA & C. dactylon, V. negundo & Liu et al., 2016 \\
\hline Loam & Mixture & $1.31-1.39$ & 0.56 & 0.72 & 26 & NA & $0.40-5.84$ & C. dactylon, V. negundo & Liu et al., 2016 \\
\hline Loam & Fibrous & 1.21 & 0.41 & 0.36 & 409 & $0.30-17.98$ & NA & P. virgatum & Zhang et al., 2013 \\
\hline
\end{tabular}

*Mixture refers to a mixture of fibrous and tap roots. BD is topsoil bulk density, $\mathrm{b}$ is parameter value of Eq. 1, $\mathrm{n}$ is number of observations, NA is not available. 
Table 2: Treatment and soil characteristics of the experimental plots.

\begin{tabular}{|c|c|c|c|c|c|c|c|c|}
\hline Treatment & Texture & $\begin{array}{c}\text { sand } \\
(\%) \\
\end{array}$ & $\begin{array}{l}\text { silt } \\
(\%) \\
\end{array}$ & $\begin{array}{l}\text { clay } \\
(\%)\end{array}$ & $\begin{array}{c}\text { SOM } \\
(\%) \\
\end{array}$ & $\begin{array}{c}\mathbf{S M} \\
\left(\mathrm{g} \mathrm{g}^{-1}\right) \\
\end{array}$ & $\begin{array}{c}\text { BD } \\
\left(\mathrm{g} \mathrm{cm}^{-3}\right) \\
\end{array}$ & Source \\
\hline $\begin{array}{c}\text { Grass } \\
\text { Carrots } \\
\text { Root-free bare }\end{array}$ & Sand & 94 & 4 & 2 & 4.5 & $\begin{array}{l}0.22 \pm 0.05 \\
0.25 \pm 0.02 \\
0.25 \pm 0.02\end{array}$ & $\begin{array}{l}1.10 \pm 0.09 \\
1.01 \pm 0.03 \\
1.12 \pm 0.10\end{array}$ & This study \\
\hline $\begin{array}{c}\text { Grass } \\
\text { Carrots } \\
\text { Root-free bare }\end{array}$ & Sandy loam & 56 & 36 & 8 & $<0.5$ & $\begin{array}{l}0.18 \pm 0.03 \\
0.17 \pm 0.04 \\
0.17 \pm 0.04\end{array}$ & $\begin{array}{l}1.31 \pm 0.14 \\
1.30 \pm 0.12 \\
1.31 \pm 0.13\end{array}$ & $\begin{array}{l}\text { De Baets et al., } \\
2010\end{array}$ \\
\hline $\begin{array}{c}\text { Grass } \\
\text { Carrots } \\
\text { Root-free bare }\end{array}$ & Silt loam & 22 & 69 & 9 & 3.4 & $\begin{array}{l}0.19 \pm 0.05 \\
0.19 \pm 0.06 \\
0.19 \pm 0.05\end{array}$ & $\begin{array}{l}1.13 \pm 0.16 \\
1.16 \pm 0.13 \\
1.17 \pm 0.17\end{array}$ & $\begin{array}{l}\text { De Baets et al., } \\
2010\end{array}$ \\
\hline
\end{tabular}

*SOM is organic matter content, SM is soil moisture content and BD is dry soil bulk density. 
Table 3: Characteristics of plants grown in the experimental treatments.

\begin{tabular}{|c|c|c|c|c|c|c|c|}
\hline Treatment & Species & $\begin{array}{c}\text { SD } \\
\left(\text { seeds } \mathrm{m}^{-2}\right)\end{array}$ & $\begin{array}{c}\mathbf{R D} \\
\left(\mathrm{kg} \mathrm{m}^{-3}\right)\end{array}$ & $\begin{array}{c}\mathbf{R L D} \\
\left(\mathrm{km} \mathrm{m}^{-3}\right)\end{array}$ & $\begin{array}{c}\mathbf{D} \\
(\mathrm{mm})\end{array}$ & $\bar{n}$ & $\begin{array}{l}\text { Texture } \\
\text { (Source) }\end{array}$ \\
\hline $\begin{array}{r}\text { Grass } \\
\text { (mixture) }\end{array}$ & $\begin{array}{l}\text { L. perenne spp. L. }(75 \%) \text {, } \\
\text { P. pratense }(15 \%) \text {, } \\
\text { P. pratensis }(10 \%)\end{array}$ & $5250 ; 10500$ & $0.01-2.26$ & $1.27-283.46$ & 0.2 & 54 & $\begin{array}{c}\text { Sand } \\
\text { (This study) }\end{array}$ \\
\hline Carrots & D. carota & $2625 ; 5250$ & $0.00-9.14$ & $0.94-19.56$ & $0.2-17.77$ & 17 & \\
\hline $\begin{array}{r}\text { Grass } \\
\text { (mixture) }\end{array}$ & $\begin{array}{l}\text { L. perenne spp. L. (48\%), } \\
\text { F. rubra }(12 \%), \\
\text { F. arundinacea }(40 \%)\end{array}$ & $5250 ; 10500$ & $0.20-38.70$ & $31.59-6228.77$ & 0.2 & 24 & $\begin{array}{l}\text { Sandy loam } \\
\text { (De Baets } \\
\text { et al., 2010) }\end{array}$ \\
\hline Carrots & D. carota & $2625 ; 5250$ & $0.13-10.61$ & $0.35-9.31$ & $9.8-20.0$ & 30 & \\
\hline $\begin{array}{r}\text { Grass } \\
\text { (mixture) }\end{array}$ & $\begin{array}{l}\text { L. perenne spp. L. }(48 \%) \text {, } \\
\text { F. rubra }(12 \%), \\
\text { F. arundinacea }(40 \%)\end{array}$ & $5250 ; 10500$ & $0.10-16.87$ & $2.27-365.75$ & 0.2 & 42 & $\begin{array}{l}\text { Silt loam } \\
\text { (De Baets } \\
\text { et al., 2010) }\end{array}$ \\
\hline Carrots & D. carota & $2625 ; 5250$ & $0.09-15.49$ & $0.38-20.15$ & $1.4-17.0$ & 30 & \\
\hline
\end{tabular}

*SD is seed density (2 treatments), RD is root density (range), RLD is root length density (range), D is mean root diameter (range) and $\mathrm{n}$ is the number of observations. 
Table 4 Non-linear regression results for the combined effects of root architecture and soil texture on the erosion-reducing potential of plant roots. Underlined parameter estimates are significant at the $5 \%$ level.

\begin{tabular}{|c|c|c|c|c|c|c|c|c|}
\hline Root type and variable & Tested relationship & Parameter & Estimate & Texture & Equation & $\mathbf{n}$ & $\mathbf{R}^{\mathbf{2}}$ & ME \\
\hline \multirow[t]{3}{*}{ Grass; RD } & $S D R=e^{-b * R D} e^{-c * R D * D_{s 1}} e^{-d * R D * D_{s 2}}$ & $\mathrm{~b}$ & $\underline{0.87}$ & Sand & $S D R=e^{-17.46 * R D}$ & 54 & 0.61 & 0.60 \\
\hline & & c & 16.58 & Sandy loam & $S D R=e^{-0.87 * R D}$ & 24 & 0.80 & 0.80 \\
\hline & & $d$ & $\underline{1.75}$ & Silt loam & $S D R=e^{-2.63 * R D}$ & 42 & 0.32 & 0.30 \\
\hline \multirow[t]{3}{*}{ Grass; RLD } & $S D R=e^{-b * R L D} e^{-c * R L D * D_{s 1}} e^{-d * R L D * D_{s 2}}$ & $b$ & $\underline{0.01}$ & Sand & $S D R=e^{-0.15 * R L D}$ & 54 & 0.58 & 0.56 \\
\hline & & c & $\underline{0.14}$ & Sandy loam & $S D R=e^{-0.01 * R L D}$ & 24 & 0.80 & 0.80 \\
\hline & & $d$ & $\underline{0.01}$ & Silt loam & $S D R=e^{-0.02 * R L D}$ & 42 & 0.32 & 0.30 \\
\hline \multirow[t]{3}{*}{ Carrots; RD } & $S D R=e^{-b * R D} e^{-c * R D * D_{s 1}} e^{-d * R D * D_{s 2}}$ & $\mathrm{~b}$ & $\underline{0.70}$ & Sand & $S D R=e^{-0.16 * R D}$ & 17 & 0.02 & -2.40 \\
\hline & & c & $\underline{-0.54}$ & Sandy loam & $S D R=e^{-0.70 * R D}$ & 30 & 0.25 & 0.05 \\
\hline & & $d$ & $\underline{-0.09}$ & Silt loam & $S D R=e^{-0.61 * R D}$ & 30 & 0.12 & -0.11 \\
\hline \multirow[t]{3}{*}{ Carrots; RLD } & $S D R=e^{-b * R L D} e^{-c * R L D * D_{s 1}} e^{-d * R L D * D_{s 2}}$ & $\mathrm{~b}$ & 1.32 & Sand & $S D R=e^{-0.11 * R L D}$ & 17 & 0.37 & 0.33 \\
\hline & & c & $\overline{-1.21}$ & Sandy loam & $S D R=e^{-1.32 * R L D}$ & 18 & 0.07 & -0.30 \\
\hline & & $d$ & $\underline{-1.08}$ & Silt loam & $S D R=e^{-0.24 * R L D}$ & 28 & 0.07 & -0.04 \\
\hline
\end{tabular}

* RD $\left(\mathrm{kg} \mathrm{m}^{-3}\right)$ is root density, $R L D\left(\mathrm{~km} \mathrm{~m}^{-3}\right)$ is root length density; $D_{s 1}$ and $D_{s 2}=$ dummy soil: Sand $\left(D_{s 1}=1, D_{s 2}=0\right) ;$ Sandy loam $\left(D_{s 1}=0, D_{s 2}=0\right)$ and silt loam $\left(D_{s 1}=0, D_{s 2}=1\right) ; n$ is the number of observations; $\mathrm{ME}$ is model efficiency; $\mathrm{R}^{2}$ is coefficient of determination. 
Table 5 Non-linear regression results for the combined effects of root architecture and soil texture on the erosion-reducing potential of plant roots. Underlined parameter estimates are significant at the 5\% level, parameter estimates indicated with * are significant at the $1 \%$ level.

\begin{tabular}{|c|c|c|c|c|c|c|c|c|}
\hline Root type and variable & Tested relationship & Parameter & Estimate & Equations & & $\bar{n}$ & $\mathbf{R}^{\mathbf{2}}$ & ME \\
\hline \multicolumn{9}{|c|}{ Combined root architecture and soil texture effects (Root diameter as continuous variable) } \\
\hline \multirow[t]{2}{*}{ Carrots, sand; RD } & $S D R=e^{-b * R D} e^{-c * R D * D}$ & b & 0.48 & Sand & ns & 17 & - & - \\
\hline & & c & 0.02 & & & & & \\
\hline \multirow[t]{2}{*}{ Carrots, sandy loam; RD } & $S D R=e^{-b * R D} e^{-c * R D * D}$ & $\mathrm{~b}$ & $\underline{1.23}$ & Sandy loam & $S D R=e^{(-1.23+0.06 * D) * R D}$ & 18 & 0.18 & 0.07 \\
\hline & & c & $\underline{-0.06}$ & & & & & \\
\hline \multirow[t]{2}{*}{ Carrots, silt loam; RD } & $S D R=e^{-b * R D} e^{-c * R D * D}$ & $b$ & $\underline{\underline{1.75}}$ & Silt loam & $S D R=e^{(-1.75+0.11 * D) * R D}$ & 28 & 0.65 & 0.65 \\
\hline & & c & -0.11 & & & & & \\
\hline \multirow[t]{2}{*}{ All species, sand; RD } & $S D R=e^{-b * R D} e^{-c * R D * D}$ & $b$ & $\overline{15.67}$ & Sand & $S D R=e^{(-15.67+0.88 * D) * R D}$ & 71 & 0.40 & 0.25 \\
\hline & & c & $\overline{-0.88}$ & & & & & \\
\hline \multirow[t]{2}{*}{ All species, sandy loam; RD } & $S D R=e^{-b * R D} e^{-C * R D * D}$ & $b$ & $\underline{1.01}$ & Sandy loam & $S D R=e^{(-1.01+0.05 * D) * R D}$ & 42 & 0.50 & 0.48 \\
\hline & & c & $\underline{-0.05}$ & & & & & \\
\hline \multirow[t]{2}{*}{ All species, silt loam; RD } & $S D R=e^{-b * R D} e^{-c * R D * D}$ & $b$ & $\underline{\underline{2.15}}$ & Silt loam & $S D R=e^{(-2.15+0.13 * D) * R D}$ & 70 & 0.47 & 0.46 \\
\hline & & c & -0.13 & & & & & \\
\hline \multicolumn{9}{|c|}{ Combined root architecture and soil texture effects (Root diameter, sand content and dry soil bulk density as continuous variables) } \\
\hline \multirow[t]{4}{*}{ All species, all soils; RD } & $S D R=e^{-b * R D} e^{-c * R D * D} e^{-d * R D * \% S} e^{-e * R D * B D}$ & b & $\underline{2.23}$ & \multirow{4}{*}{\multicolumn{2}{|c|}{$S D R=e^{(-2.23+0.12 * D-0.07 * \% S+1.35 * B D) * R D}$}} & 183 & 0.32 & 0.17 \\
\hline & & c & $\overline{-0.12}$ & & & & & \\
\hline & & d & $\overline{0.07}$ & & & & & \\
\hline & & e & $\underline{-1.35}$ & & & & & \\
\hline \multirow[t]{3}{*}{ Carrots $(<5 \mathrm{~mm})$, all soils; RD } & $S D R=e^{-b * R D} e^{-c * R D * D} e^{-d * R D * \% S}$ & $\mathrm{~b}$ & $2.94^{*}$ & \multirow{3}{*}{\multicolumn{2}{|c|}{$S D R=e^{(-2.94+1.06 * D-0.05 * \% S) * R D}$}} & 14 & 0.48 & 0.45 \\
\hline & & c & $-1.06^{*}$ & & & & & \\
\hline & & $d$ & $\underline{0.05^{*}}$ & & & & & \\
\hline \multirow[t]{2}{*}{ Carrots (> $5 \mathrm{~mm}$ ), all soils; RD } & $S D R=e^{-b * R D} e^{-c * R D * D}$ & $\mathrm{~b}$ & $\overline{0.84}$ & \multirow{2}{*}{\multicolumn{2}{|c|}{$S D R=e^{(-0.84+0.04 * D) * R D}$}} & 49 & 0.17 & 0.09 \\
\hline & & c & -0.04 & & & & & \\
\hline \multirow[t]{3}{*}{ Grass, all soils; RD } & $S D R=e^{-b * R D} e^{-c * R D * \% \text { sand }} e^{-d * R D * B D}$ & b & $\overline{6.80}$ & \multirow{3}{*}{\multicolumn{2}{|c|}{$S D R=e^{(-6.80-0.08 * \$ \text { sand }+4.85 * B D) * R D}$}} & 120 & 0.36 & 0.30 \\
\hline & & c & $\overline{0.08}$ & & & & & \\
\hline & & $d$ & -4.85 & & & & & \\
\hline
\end{tabular}

* $\mathrm{RD}\left(\mathrm{kg} \mathrm{m}^{-3}\right)$ is root density; $\mathrm{D}(\mathrm{mm})$ is root diameter (continuous variable); $\mathrm{BD}\left(\mathrm{g} \mathrm{cm}^{-3}\right)$ is dry soil bulk density (continuous variable); \%sand is sand content (values ranging between 0 and 100); $\mathrm{n}$ is number of observations; $\mathrm{ME}$ is model efficiency; $\mathrm{R}^{2}$ is coefficient of determination; $\mathrm{ns}$ means not significant. 